2016-07-30

\title{
Developing Local Partnerships in HPE (Win, Win, Win)
}

Lynch, TJ

http://hdl.handle.net/10026.1/6374

10.1007/978-3-319-31667-3_7

Springer International Publishing

All content in PEARL is protected by copyright law. Author manuscripts are made available in accordance with publisher policies. Please cite only the published version using the details provided on the item record or document. In the absence of an open licence (e.g. Creative Commons), permissions for further reuse of content should be sought from the publisher or author. 


\title{
Developing Local Partnerships in HPE (Win, Win, Win)
}

\begin{abstract}
The community collaborative partnership was extended in semester one 2012 as part of unit EDF3619 'Sport and physical activity education'. The purpose of this chapter is to share insights of this programme. A key goal for the 'Friday Sports' programme was to be a worthwhile and valued experience for the children, and especially, for the four new partnering schools. The partnership enabled accessing new assets for each of the stakeholders and subsequently, enhancing the quality of the learning experience, which they otherwise would not have had. Feedback from the various stakeholders evidenced that the 'Friday Sports' programme was successful and very popular.
\end{abstract}

The community collaborative partnership was extended in semester one, 2012. This was the second of the six units in the Primary Education Physical Education stream to involve local primary schools. In semester one, 2011 as discussed in detail in Chap. 3, a pathway was created through the implementation of swimming and water safety education in Primary schools. Teacher education students studying the unit EDF2611 'Experiencing Aquatic Environments' as an elective gained swimming and water safety discipline knowledge and subsequently qualifications (a Victorian Institute of Teachers registration requirement) in the Australian Swimming Coaches and Teachers Association (ASCTA)—Swim Australia 
Teacher (SAT), Royal Life Saving Society Australia (RLSSA) Bronze Medallion and RLSSA Resuscitation courses.

Discussion of the sports partnership implemented as part of unit EDF3619 'Sport and physical activity education' has been presented with reference to the International Civil Society Centre (ICSC) 'Nine building blocks for successful partnerships' (2014, p. 14).

\section{Actors}

\section{Leadership}

Primary education Initial Teacher Education (ITE) university students (pre-service teachers), choosing the physical education (PE) major stream at Monash University (Gippsland campus), studied the unit EDF3619 'Sport and physical activity education'. Amendments were made to this unit by the leader so that the 'Friday Sports' programme would potentially benefit all stakeholders; namely pre-service teachers, local school communities, and the local health industry. This programme ran over five weeks and was the first university-school partnership programme of this nature to be implemented within the Gippsland area.

Leadership involved initiating programme discussions, which was essential for this learning opportunity to be created. Communication initially comprised personal face-to-face relations between the leader and the primary school principals. In January of 2012, during pupil free days for the primary schools, the programme leader visited the three closest Churchill primary schools to meet with the Principals. In some schools, the Principal was available and a meeting/discussion occurred where the leader could share his vision of the pre-service teachers conducting various sports sessions at no cost for the primary children on a Friday. This also gave the Principal the opportunity to share their interest and thoughts in this proposed sports programme. If the school Principal was not available, an appointment was made for a convenient time to meet and contact details were exchanged. Furthermore, a brief explanation of the project was given to the next person in charge. After the three Churchill schools had confirmed their willingness to participate, the number of children was calculated. There were enough teacher education students (40) to involve more than the three Churchill schools, all of which were within walking distance to the facilities.

The leader extended the invitation to other surrounding schools to participate following the same process, namely, visiting schools to meet principals. Having been employed as a Head Teacher in a large school, 
Start' programme. Moreso, the leader did not want to burden school communities with thoughts requiring extra time and effort. However, suggestions were made by the leader that there would be good opportunities in the future for grant applications to assist with the programme which may possibly involve some research. Such possibilities were well received by the teachers during discussions. Hence, trust was building and relations were being strengthened between the leader and teachers.

Again, it was the purpose of the leader to "be transparent in communicating successes and drawbacks, strategies, reports and evaluations" (ICSC 2014, p. 25). This was achieved in a paper presented and discussed at the '28th National Society for the Provision of Education for Rural Australia (SPERA) conference' in September, 2012. The paper was later published in the Australian and International Journal of Rural education and was titled 'Community collaboration through sport: bringing schools together' (Lynch 2013a). Communication of programme successes and drawbacks was also written and later published in the Asia-Pacific Journal of Health, Sport and Physical Education in 2013, titled 'School Centres for Teaching Excellence (SCTE): understanding new directions for schools and universities in health and physical education'. Publications and presentations were warmly received by various educationalists. (Lynch 2013c).

This Friday Sports programme was designed using international 'best practice' within PETE. Data was gathered by the leader in early January of the same year. The data gathering UK PETE case study inspired the leader to commit to the programme.

\section{REFERENCES}

Australian Swimming Coaches and Teachers Association (ASCTA). (2011). Swim Australia Teacher (SAT) course evaluations summary. Beerwah, QLD: Author. Clayton, B., Blom, K., Bateman, A., \& Carden, P. (2004). What works where you are? The implementation of training packages in rural Australia. Retrieved from http://files.eric.ed.gov/fulltext/ED495190.pdf

International Civil Society Centre. (2014). Multi-stakeholder partnerships: Building blocks for success. Retrieved from https://icscentre.org/downloads/14_10_02_ Multi-Stakeholder_Partnerships.pdf

Lynch, T. (2013a). Community collaboration through sport: Bringing schools together. Australian and International Journal of Rural Education, 23(1), $9-22$. 
Lynch, T. (2013b). 'Poison ball' or a magic potion? Secrets within an infamous game. Australian Council for Health, Physical Education and Recreation (ACHPER) Active and Healthy Magazine, 20(2), 19-21. doi:10.13140/2.1.3282.8806.

Lynch, T. (2013c). School centres for teaching excellence (SCTE): understanding new directions for schools and universities in health and physical education. Asia-Pacific Journal of Health, Sport and Physical Education, 4(3), 249-266. http://www.tandfonline.com/doi/full/10.1080/18377122.2013.836770\#. U3kgMaSKBok

Monash University Faculty of Education. (2012). EDF3619 sport and physical activity education unit evaluation report. Retrieved from https://unitevaluations.connect.monash.edu.au/unitevaluations/wr/uewr_rpl_public. jsp? semester $=1$ \&year $=2012 \&$ report_scope $=U \&$ faculty_cd $=50000564 \&$ unit cd=EDF3619\&ref_unit_cd=no_ref_cd

Siedentop, D. (1994). Sport education: Quality PE through positive sport experiences. Champaign, IL: Human Kinetics. 